\title{
Covid-19 and Crisis Management: The Necessity of Innovation in the Business Model of SMEs in Order to Recover and Develop Fast After the Corona Crisis
}

Sina Mirzaye ( $\square$ sinamirzaye@gmail.com )

Islamic Azad University

\section{Research}

Keywords: Business model innovation, SMEs, COVID-19, Crisis

Posted Date: November 15th, 2021

DOl: https://doi.org/10.21203/rs.3.rs-1031041/v1

License: (1) (1) This work is licensed under a Creative Commons Attribution 4.0 International License. Read Full License 


\section{Abstract}

We know that SMEs are among the businesses most affected by the COVID-19 shutdown. The first theoretical and practical observations in SMEs show that innovation in business models can be a solution to successfully improve and cope with the COVID-19 crisis. In a way that arouses curiosity, some SMEs have already begun to successfully change and reconciling their business models. This paper provides a qualitative analysis of six local SMEs in Iran to explore how SMEs adapt their business models to crisis. We collected interview data from managers with one of their middle managers for each case, which we triangle for analysis with secondary data. According to the results, BMI could be used during and after a crisis to generate new income, maintain and exit precrisis conditions, and develop.

\section{Introduction}

Crisis management is the identification of possible threats an organization face to, and the methods used by that organization to deal with the threats. Naturally, crisis management involves all the decisions that are actually made and the actions that are taken. When a critical event occurs, the crisis management department in a company should make strategic decisions to minimize economic losses and maximize the flexibility of the organization (Herbane, 2013). Small companies may be more vulnerable to critical situations as they are suffering from less resources and a weaker market position. However, small and medium-sized companies also have advantages, including flexibility, adequate learning capacity, innovation and good customer relations (Hong \& Li, 2012; Irvine \& Anderson, 2006;).

Small and medium-sized companies make up more than $90 \%$ of established companies worldwide. That is why they are called the backbone of the global economy (Tannenbaum et al., 2020). Although these companies play an important role, due to their relatively vulnerable financial position, the Covid-19 crisis has become a major threat to them (Doshi et al., 2018; Herbane, 2010)

The Covid-19 crisis appeared in China in late 2019 and soon became a global epidemic crisis (Lok, Tan Cheng et al., 2021). The outbreak of this virus has so far had serious effects on sectors of the world, including health and the economy (Rao, H. Raghav et al., 2020). In addition to the human catastrophe caused by the Corona virus, the virus has also hit local and global economies hard (GDA, 2020).

Although the Covid-19 epidemic crisis is a threat to the performance and efficiency of businesses (Boin, 2009; Williams et al., 2017), concerns about the consequences of this epidemic and the various responses of governments (including quarantine, social distancing rules, etc.) will affect small and mediumsized businesses (Thorgren and Williams, 2020). Today, business environments are chaotic and constantly changing (Brosseau, et al., 2019). The current destructive situation caused by the global Covid-19 epidemic is a clear example of this turmoil and change. Today, many organizations, especially small and medium-sized companies, are no longer able to achieve continuous growth using development strategies that used to be effective for several years, so they are trying to innovate and create new programs to stay in market for a few more months (Blackburn et al., 2020). Although government aid is often considered to be the most important factor in rescuing industries in crises, the impact of crises on the business model, especially the Covid-19 crisis on the current business model, is significant (Ritter and Pedersen, 2020).

What is a business model? Business model is the way companies operate to create value, offer value and gain value within the model (Beqiri, 2014). To operate within this framework, critical issues must be considered: goal classification, product or service delivery, revenue model, value chain, cost model and organization. Recreating at least two of these items in a business model to provide value in a new way is called business model innovation. Business model innovation is more important than mere innovation in technology, product or service as it involves a multidimensional and coordinated activity that is challenging to implement and difficult to emulate (Lindgardt et al., 2009). To have an effective innovative business model, small and medium-sized businesses must be well aware of innovative business models (Mohamad 2018).

Given what have been said, this question arises: Can an innovative business model lead to the rapid growth and recovery of small and medium-sized businesses in the Covid-19 crisis and its aftermath?

\section{Literature Review}

\section{Crisis management for small and medium-sized businesses:}

Small and medium-sized companies have less resources under their control due to their small nature (Freeman, Carroll, \& Hannan, 1983). This has led to their higher level of vulnerability due to events such as the loss of an important employee, a decrease in market share due to the entry of new competitors, or the case that this research addresses: the Covid-19 crisis, which has affected the global economy (Eggers, 2020). So far, many studies have addressed the issue of crisis management in small and medium-sized companies from different perspectives. The results show that the lack of external financial support and training process in crisis (Herbane, 2010), problems caused by government decisions (Runyan, 2006), lack of comprehensive and formal crisis management program (Perry, 2001) and underestimating crises (Spillan and Ziemnowicz, 2003) are among the most important issues involving small and medium-sized businesses in crises. Existence of following items are among the basic ideas for handling these crises: a program to save lives and to recover in crisis (Munoz et al. 2019), a crisis management team (Ruff \& Aziz 2003) or a crisis notification system (Kurschus et al. 2015). In general, flexibility and a comprehensive plan are highly needed when managing difficult crises. Companies should try to reorganize their activities by presenting strategies in a timely manner (Ansell et al., 2010).

\section{Innovation in small and medium-sized businesses}

Innovation is one of the most important sources of competitive advantage and is essential for business development (OECD, 2005). Some researchers believe that innovative activities in small and medium-sized companies are influenced by the manager's views (O'Regan et al., 2006). This is why the culture in small 
and medium-sized businesses is largely influenced by subjective approaches (personal beliefs, feelings, and experiences) that affect the decision-making process about prioritizing innovation projects (Gherardini et al., 2017). Enjoying an organizational culture that supports values, behaviors, and beliefs can lead to innovation in small and medium-sized businesses (Bessant and Tidd, 2013). Just as culture affects innovation in the business model (Hock et al., 2016), enjoying an organizational culture that promotes creativity and innovation can also encourage business employees to take risks, come up with ideas, and take advantage of opportunities (Aksoy, 2017).

\section{Innovation in the small and medium-sized companies' business model in crisis}

A business model for a company is generally a way to create value, distribute value, and gain value for its consumers, shareholders, and partners (Bouwman et al., 2008). Crises can create new business models by creating new capabilities, value creation and new values capture (Chisholm-Burns, 2010). Companies that are fully aware all aspects of their business model and have worked actively on it are more successful in crisis (cf. Baker-Brunnbauer 2019). In this difficult circumstance, businesses need to look at it as a leverage to start over, rather than adopting defensive tactics and applying price changes (Baghiu, 2021). A business model consists of two main parts: value proposition and operational model; each has three subgroups [...]. When at least two elements of a business model are recreated to present value in a new way, innovation in the business model is formed. Because this includes multi-dimensional and coordinated activities (Lindgardt et al., 2009). Innovation in the business model is the most effective way for companies to resist and stand against competitors to ensure the life of the organization, especially in conditions of uncertainty (Tinku, 2019). Business model innovation is more effective than product or process innovation (Baghiu, 2021). The results of a study confirm that innovation in the business model is a key activity that shall be done continuously in all countries, whether to maintain the organization's existence or to strengthen its growth (Hanelt, Hildebrandt, and Polier, 2015). Of course, it should not be denied that another important goal of innovation in the business model is to earn more in different ways, which are created by innovation in performance and competitive mentality among competitors for survival in the industry (Mohamad 2018; Sebastian 2018). Business model innovation is a concept that small and medium-sized companies shall first understand to be useful for their growth in the market (Husin et al. 2018). Surprisingly, many small and medium-sized companies are still not fully aware of the benefits of innovation in business model and its concept (Jones and Pimdee, 2017). Understanding this concept allows small and medium-sized companies to take advantage of opportunities (Girotra and Netessine 2013). Studies show that ignorance of this concept plays a role in the failure of small and medium-sized businesses (Zulkifly, 2018). Even with the right start-up model, small and medium-sized companies are not aware of the need to be innovative when facing of changes that may occur during an organization's life cycle (Husin et al., 2021). Albeit, sometimes it is not possible to recognize a concept alone, and small and medium-sized businesses shall work together to increase the level of innovation (oleskow-szlapka et al., 2017). The stimulus that can lead to innovation in the business model can be internal or external (Foss \& Saebi, 2017); the most important internal factor is the customer-related changes (Huang et al., 2012) and the most important external factor is the environment (Sorescu et al., 2011). Of course, business model innovation is the result of external stimuli, such as sweeping changes in the business environment (De Reuver et al., 2013). Today, given the turbulent environments we live in, business models that have been successful so far may not be able to continue to be profitable (Chesbrough, 2007, 2010). Thus, as a competitive advantage, we need to think about recreating our business model before circumstances force us to (Hamel and Valikangas, 2004, p. 53). Usually in critical environments, small and medium-sized business managers do not have the right attitude to create, acquire and provide value to customers and companies (Marolt et al., 2018). Therefore, innovation in the business model can be an opportunity to recreate these values (Pohle and Chapman, 2006).

\section{Methodology}

Since the purpose of this study is to understand the impact of an innovative business model on small and medium-sized companies affected by the Covid-19 crisis and the impact of innovation on business growth and recovery, multiple case study method has been selected to study this real and complicated phenomenon for which just a little theoretical sources were available. The use of this method will further strengthen the findings of the research. Studies on small and medium-sized companies' business models and the impact of regional crises on small and medium-sized businesses have been conducted. However, a few studies have been done on innovation small and medium-sized enterprises' business model in crisis; and they are rare in crises like Covid-19. Therefore, the qualitative approach of our research tries to develop the existing theory.

Since case studies cannot be generalized to a community with certainty, this study can be considered as an idea for other research in the field of small and medium-sized businesses as well as innovation in business model; and to be rejected or confirmed by quantitative research.

To achieve the research goal, we used 6 small and medium-sized companies in Iran (Table 1) that were able to show good success in dealing with the Covid19 crisis as well as recovering their business in this critical situation and successive quarantines in Iran. In order to reinforce the findings, these companies have been selected from various industrial and service sectors. Moreover, the different fields of activity causes to examine the views of these companies' managers dealing with this crisis and the approach they have used to overcome it, from different perspectives. It should be noted that a company in Iran is known as small and medium that has less than 50 employees.

Table 1

Information about Cases 


\begin{tabular}{|lllll|}
\hline Business Name & Industry & $\begin{array}{l}\text { Number of } \\
\text { Employees }\end{array}$ & Year of foundation & Crisis \\
\hline 1 & Restaurant & 22 & 4 & Management Experience \\
\hline 2 & Hotel & 25 & 10 & Yes, but not related \\
\hline 3 & Clothes & 7 & 3 & Yes \\
\hline 4 & Private Education & 17 & 15 & No \\
\hline 5 & Wholesale and Distribute & 19 & 6 & Yes \\
\hline 6 & Construction & 37 & 20 & No \\
\hline
\end{tabular}

\section{Data collection}

In order to answer the research question, two interviews were conducted between February and March 2016. One with the manager/ owner of the small and medium-sized companies and the other with their sales/ financial manager. In order to reduce physical contact and follow health protocols regarding Corona virus, these semi-structured interviews were conducted through social media. With the permission granted by all interviewees, all sessions were recorded.

According to the information obtained from social media as well as the information available to companies in the Ministry of Industry, Mines and Trade of Iran and also the State Statistics Organization, Triangulation Strategy has been used. Moreover, in order to increase the validity of the data, the written version of the interviews has been sent to the interviewees for their approval.

\section{Data analysis}

Analytical strategies of pattern matching and construction analysis were adopted to compare data yielded from the six selected companies [a restaurant, a hotel, a clothing company, an educational institution, a distribution company, and a construction company] encoded by the numbers $(1,2,3,4,5,6)$ in a withincase and cross-case analysis (Yin,1994; Hong \& Li, 2012). In data analysis, cases were compared with each other and their similarities and contradictions were recorded. In order to strengthen the reliability and validity of the results, the findings of the study were compared to the predicted data which have been already expressed by industry experts.

\section{Cases Description}

\section{The first case - A restaurant}

The first case is a restaurant with Iranian and foreign cuisine established about 4 years ago. Family members are handling accounting and management departments. In total 22 people work in this restaurant, three of whom are members of the restaurant owner's family. The 65-year-old restaurant manager is an experienced person who has experienced crises in the past in his previous businesses that were different from the restaurant business. Due to its good location and menu with a high variety of food, this restaurant was able to achieve high popularity and fame in a short time after its establishment. This restaurant with a large and open garden as well as a hall with a modern design has been able to attract the attention of a wide range of customers.

\section{The second case - A hotel}

The second case is a hotel located in a coastal area in northern Iran. The manager and owner bought the complex 10 years ago. He makes all the managerial decisions himself; as he is an experienced person with lessons learned from the past crises. The hotel has 60 beds and 12 employees. There are two nonnative employees and they work in this hotel while studying. The main income of this hotel is related to Nowruz holidays and summer. It has a restaurant that only serves hotel guests and does not serve food independently.

\section{The third case - A clothing company}

The third case is a clothing design and production company that was founded 3 years ago by two entrepreneurs. The company started in a rented place and has seven employees. In addition to the store, the company has launched its products through websites and social media. The company needs the approval of both to execute the new orders. None of them has practical experience in dealing with the crisis. The company's store is not located in a crowded street. Therefore, the main way for them to earn money is to sell online.

\section{The fourth case - An educational institute}

The fourth case is a foreign language institute. This institute was established 15 years ago and has thirteen employees among them are two non-native language teachers and they are working in this institute while studying. The manager of this academy has been selected by the company's owner. The manager has good experience in handling the past crises. Usually, the income from this institution is almost the same during the year; in other words, it is not a seasonal job. The location of the company has not changed since its establishment, this institute holds all its training classes inside the venue, and it is an independent place.

\section{The fifth case-A Distribution Company}


The fifth company is a sports supplement distribution company that works directly with pharmacies and the gyms. The company operates in a rented place and has nine personnel. It has been 6 years since the company was founded and its manager has no experience in crises. Three cars do the products distribution in this company and cover about 20 cities.

\section{The sixth case - A construction company}

The sixth company is a construction company with more than 20 years of experience. This company operates in the field of design and construction of commercial and residential units and has 37 employees. Its manager is an experienced person in the field of crises that have occurred in Iran who has been able to develop the company and reach profitability during these years. The owner of this company is its manager as well.

\section{Results}

\section{Within case analysis}

The following analysis provides an insight into the individual cases. Table 2 provides an overview of the main components of the cases.

\section{Case 1 - the restaurant}

The restaurant was severely affected by the Corona Virus crisis and successive quarantines. During the first quarantine, it had no income due to lack of takeout services. However, during the crisis, successful innovations have been created in the business model, largely by the manager. Working with a local food delivery service not only reduced the cost of human resources for hiring and training, but also generated revenue from the takeout-restaurant service. Moreover, offering discount coupons on each order for the subsequent orders in the takeout services made customers more willing to re-order. After reopening the restaurant, innovation in arranging chairs both in the garden and the indoor space (using cartoon character dolls for indoor tables to maintain the social distance and creating rooms in the shape of ancient Iranian houses for the garden environment for maintaining social distance attracted customers and made it more popular. The restaurant did not lay off its staff after this innovation while during the first quarantine; it forced the all staff to take a leave of absence.

\section{Case 2- the hotel}

The hotel was severely affected by the Corona Virus crisis. Because its lucrative period coincided with government-imposed quarantines. This hotel has laid out its entire staff. According to the hotel manager, he has always been trying to create innovation, but the widespread impact of the virus on the tourism industry as well as the hotel's coastline location and its and distance from urban areas, made the manager lose his hope regarding the impact of innovation. The hotel manager tried to boost his business by collaborating with travel agencies after the reopening of businesses, but due to inter-city restrictions as well as restrictions on visiting the coastal areas of northern Iran applied by the government, the hotel faced its worst critical period and this innovation was not successful. The firm has once used government grants and hopes to revive its business by easing travel restrictions on coastal and interurban areas.

\section{Case 3 - the clothing company}

Although the Covid-19 crisis caused a significant reduction in the company's in-person sales, but due to their major activity in the digital space, this reduction did not have much effect on their revenue. By changing the previous business model, the managers of this company were able to increase the income from their online sales by holding some competitions on social media and awarding various prizes (in order to increase interaction with customers and also the number of visits and shares). Moreover, innovation in the content production in cyberspace (creating videos for introducing products and reviewing their quality) was also effective in increasing their revenue and they hired two people to manage online networks better. In order to support the businesses damaged during the Corona, the company interacted bilaterally with other businesses active in cyberspace, so that in addition to fulfilling their social responsibility, they could create an innovation in advertising as well.

\section{Case 4 - the educational institute}

The institute was shut down completely with the Covid-19 crisis and nationwide quarantine commencement, forcing all its employees to take a leave of absence. However, in a short time, thanks to some innovations in the business model, not only they continued to hold previous classes, but also they were able to overcome the panic in the community regarding education in that situation and started registering new applicants. This institute created online classes in the web space. In addition, by advertising on the web and creating a culture in the field of online education and its necessity during Corona virus pandemic, the institute was able to continue its activities have not faced any decrease in the number of employees (non-native professors teach remotely).

\section{Case 5- the distribution company}

The company has been severely affected by the Corona virus crisis due to restrictions imposed on intercity traffic as well as the closure of sports centers (which are considered as high-risk jobs in Iran). With the closure of sports venues and the consequent sharp decline in demand for sports supplements, the company's manager rejects any innovation and believes in forcing the employees to take a leave of absence and relying on government support designed for small and medium-sized businesses until the crisis is over and the sports venues open. The company uses government loans to pay rentals for the company's venues.

\section{Case 6 - the construction company}

Due to its different field of activity in comparison to many other businesses and being away from crowded communications, the company was able to minimize the impact of the Corona crisis by observing hygienic protocols and disinfecting workplaces as well as work tools frequently. By creating innovation 
in the type of employee services and performing duties online instead of being present in the company (for employees of the software department), the company reduced the number of employees present in the company effectively. Moreover, after the restrictions on intercity traffic, instead of using field advertisements (a method adopted by this company before the crisis) the company created innovations on internet advertisements using influencers, and took part in making health educational teasers about Corona (as a sponsor) to continue its effective advertising.

Table 2

Within-case analysis overview

\begin{tabular}{|llll|}
\hline Business Name & BMI & Furlough & recruit \\
\hline 1 & Yes & Yes & Direct, No \\
\hline 2 & No & Yes & No \\
3 & Yes & No & Yes, 2 \\
\hline 4 & Yes & Yes & No \\
\hline 5 & No & Yes & No \\
\hline 6 & Yes & No & No \\
\hline
\end{tabular}

\section{Cross- Case analysis}

The results show that companies had almost the same understanding of the critical situation aroused and wanted to apply the necessary changes and cope with it, except for cases 2 and 5 , which were somewhat incapable in crisis management due to the nature of their activities and the effects of government decisions on them. Table 3 provides an overview of the main results of the cross-case analysis.

Table 3

Cross-case overview of essential factors

\begin{tabular}{|c|c|c|c|c|c|c|c|}
\hline & & 1 & 2 & 3 & 4 & 5 & 6 \\
\hline \multirow[t]{3}{*}{ BMI } & Value Creation & Yes & - & No & Yes & - & No \\
\hline & Value Proposition & Yes & - & Yes & Yes & - & Yes \\
\hline & Value Capture & Yes & - & No & Yes & - & No \\
\hline Governmental Financial Support & & - & Yes & Yes & - & Yes & - \\
\hline \multirow[t]{4}{*}{ Resilience and Recovery Strategy } & Financial optimization & - & - & Yes & - & - & Yes \\
\hline & Flexibility in HRM & Yes & Yes & Yes & Yes & - & Yes \\
\hline & Changing the Consumer Network & Yes & - & Yes & - & - & Yes \\
\hline & Explore New Markets & Yes & - & - & Yes & - & - \\
\hline
\end{tabular}

\section{The role of an innovative business model in a crisis}

Four companies (1, 2, 3 \& 4) used an innovative business model to deal with the crisis and reduce its impacts. In two cases ( 1 \& 4), companies coped with the crisis by innovating in a completely new model, different from their previous business model, in contrast to the other two cases ( 3 \& 6 ) that innovated in their previous model.

The results show that value creation in the two companies ( 1 \& 4) has changed due to the Covid-19 crisis. Instead of a modern garden and lounge, company 1 used traditional rooms and cartoon character dolls or offered various discounts on takeout orders. Company 4 also tried to achieve public acceptance by changing the value from face-to-face classes to online ones and through culture-building strategies. All four companies $(1,3,4$ \& 6$)$ have made changes in their value proposition, which in addition to changing customer base, includes new sales methods as well. Value absorption in both cases 1 and 4 must be readjusted due to a large change in the value proposition. Innovation in Business model has revolutionized all four companies in the critical period.

The reasons why these companies innovate in their business model can be related to one of the factors of time, responsibility, crisis or financial pressure.

Since the available time was the same for all cases and only four companies innovated during this time, it can be concluded that the available time is not enough for innovation in the business model. However, being in a critical situation, having financial pressure or being responsible along with time, can be the main factors of innovation in the business model.

Two other companies $(2 \& 5)$ that were unable to innovate in their business model during the crisis, decided to use government support to cover rental costs (5) and to wait for reopening sports venues or plan for using the post-corona opportunities (2) to boost coastal tourism. It seems that when there is a crisis, sometimes government decisions to control it can have deeper negative impacts on some businesses than the others, therefore makes it more difficult to be innovative. 
In all of these cases, during the first quarantine period, the most important factor that enabled companies to achieve plans for the future was the leave of absence of all employees to lessen concerns about their salary costs. The results show that small and medium-sized businesses are more vulnerable to demand decline in crisis (Cosh et al., 2009; Irvine \& Anderson, 2006; Simon-Moya et al., 2016; Phillipson et al., 2004). All of the cases have also estimated the side effects of the Covid-19 crisis on their businesses in future.

\section{How to recover and grow during a crisis}

By examining the responses of managers in the interviews and data analysis, it can be inferred that in order to maintain or recover a business or its growth in crisis, much attention should be paid to the consumer network, financial optimization, and flexibility in human resources. In the present study, four out of six cases $(1,3,4 \& 6)$ tried to strengthen their communicative connection with customers, develop their product or its presentation method to the audience and to discover new markets during the crises or thereafter.

Coping with the critical situation and then innovating in the business model caused four out of six companies to learn from these circumstances to achieve rapid growth during the corona pandemic, which can be due to the strong dynamic environment in small and medium-sized companies as well as their high capacity for innovation (Saunders et al. 2014; Bullough and Renko, 2013).

Given that cases 3 and 6 created innovation and adapted their business to the crisis and dismissed their employees only in the first quarantine for 2 weeks, while carrying out their activities; and items 1 and 4 dismissed their employees for one month to reduce costs and then created innovation; and items 2 and 5 did not created any innovation, although they dismissed all the employees until the preparation of this report, therefore, the cost management and cost reduction cannot be assumed effective in crisis management and Innovation in the business model. However, reducing human resource costs (case 1 through cooperation with the food delivery service) or managing advertising and sales costs (case 3 through advertising exchange) along with innovation can have a direct impact on maintaining and developing the business in crisis.

\section{Discussion And Conclusion}

This study shows that innovation in the business model of small and medium-sized companies during crisis can be useful for their recovery and growth. These innovations, however small, can be implemented quickly. We found that factors such as time, financial pressure, responsibility and being in a critical situation play a major role in innovation. Of course, the impact of government decisions to control and deal with critical situations can damage some businesses even more; so that the possibility of creating innovation for them becomes very difficult or even somewhat impossible.

Moreover, the proper management of a company's resources is effective in maintaining it alive and reducing the impacts of crisis on it. Although, cost management as a part of any organization's vital resources cannot be effective in creating innovation by itself, if the organizations managers use it as a factor in controlling the liquidity problem and maintaining financial resources while deciding to create essential innovations in crisis, they can both recover from the crisis and achieve growth and development.

Based on the results of this research, we present a crisis-innovation model for small and medium-sized companies (Figure 1). This model shows that small and medium-sized companies struggling with crisis can use it as a new start for their stopped businesses by innovating in their business model. The Covid-19 crisis, with its extensive economic detrimental effects, has forced companies to innovate to survive. The reinforcing factors introduced in this article try to change the business model to reduce the effects of this crisis.

In this study, the impact of crisis management in small and medium-sized companies was discussed. According to previous studies, government support and targeted advertising were among the factors contributing to overcoming crises. Our results also confirm the effectiveness of these factors on the Covid-19 crisis. However, our results try to develop previous knowledge by introducing innovation in the business model as another influential factor in overcoming crises.

Although most companies use BMIs as a temporary method to maintain liquidity in the critical circumstances, our results show that BMls can have also longterm effects on companies in critical situations including new ideas and new profitability methods. We recommend that small and medium-sized companies use long-term crisis management strategies that cover both financial and non-financial issues. In addition, senior and middle managers should always strive to develop their business model and create innovation in the model during the crisis.

Our results did not reveal any relationship between shareholders and customers with companies in order to create business improvement and survival programs, so it is recommended that small and medium-sized companies have a close cooperation with their stakeholders in order to survive and recover from the crisis, especially the Covid-19 crisis (Brunet \& Houbaert, 2007).

We also observed that there is a strong need for using technology and virtual networks during the crisis, which requires more governmental supports and the communications and IT platforms development; as the small and medium-sized companies use them as an important part of their innovation.

Our results confirm the previous studies (Irvine and Anderson, 2004; Irvine \& Anderson, 2006; Jonas et al., 2010) saying that the tourism and hotel industries are very fragile and when facing crises - in this case the Covid-19 crisis - they bear the most damages, the effects of which may even last for a long time.

\section{Limitations and future research}

This research has limitations due to the used research method and also the circumstances of Covid-19. This study is one of the first studies in the field of innovation in the business model of small and medium-sized companies in the Covid-19 crisis. Non-random selection of companies participating in this study can be one of the limitations of this study. 
Since the innovation in business model is a wide and developing field, more research is needed to be done to understand its exact impact on small and medium-sized businesses. However, this article can serve as a basis for future research. The reinforcing and inhibiting factors identified in this study should be studied in future quantitative research to enhance reliability and validity. This research has been done in six different areas of small and medium-sized companies, so in future research, for a better findings' examination, it is better to conduct comprehensive research independently in each of these areas.

\section{Abbreviations}

HRM: Human Resource Management

SMEs: Small and medium-sized enterprises

BMI: Business Model Innovation

\section{Declarations}

\section{Availability of data and materials}

Not applicable

\section{Competing interests}

Not applicable

\section{Funding}

The author(s) received no financial support for the research, authorship, and/or publication

of this article.

\section{Authors' contributions}

Not applicable

\section{Acknowledgements}

This research would not be possible without the support and cooperation of many people. The author would like to express their appreciation to all the anonymous experts who accepted our invitation to participate in this study and generously dedicated their time and expertise to this project.

\section{References}

1. Aksoy, H. How do innovation culture, marketing innovation and product innovation affect the market performance of small and medium-sized enterprises (SMEs)? Technol. Soc. 2017, 51, 133-141.

2. Ansell, C., Boin, A., \& Keller, A. (2010). Managing transboundary crises: Identifying the building blocks of an effective response system. Journal of contingencies and crisis management, 18(4), 195-207.

3. Baghiu, (2021). ANALYSIS OF BUSINESS MODEL INNOVATION IN POST-COVID ECONOMY: DETERMINANTS FOR SUCCESS. 3, 7-24. http://www.jopafl.com/uploads/issue17/ANALYSIS_OF_BUSINESS_MODEL_INNOVATION_IN_POSTCOVID_ECONOMY_DETERMINANTS_FOR_SUCCESS.p

4. Baker-Brunnbauer, J. (2019): Business Model Innovation in a Paradoxical Area of Conflict (Executive Summary), https://dx.doi.org/10.13140/RG.2.2.24272.66566.

5. Bessant, J.; Tidd, J. Managing Innovation: Integrating Technological, Market and Organizational Change; JohnWiley \& Sons: Hoboken, NJ, USA, 2013.

6. Beqiri, 2014. Innovative business models and crisis management. Procedia Economics and Finance 9 ( 2014 ) 361 - 368.

7. Blackburn,S., LaBerge, L., O’Toole, C., \& Schneider, J. (2020). Digital strategy in a time of crisis. McKinsey Digital, April 22.

8. Boin, A., 2009. The new world of crises and crisis management: implications for policymaking and research. Rev. Pol. Res. 26, 367-377.

9. Bouwman, H., Zhengjia, M., Duin, P. Van Der, \& Limonard, S. (2008). A business model for IPTV service: a dynamic framework. Info, 10(3), 22-38. https://doi.org/10.1108/14636690810874377.

10. Brosseau, D., Ebrahim, S., Handscomb, C., and Thaker, S. (2019). The journey to an agile organization. McKinsey \& Company, May 10.

11. Brunet, S., and Houbaert, P. (2007). Involving Stakeholders: The Belgian Fowl Pest Crisis. Journal of Risk Research,10(5), 643-660.

12. Bullough, A., \& Renko, M. (2013). Entrepreneurial resilience during challenging times. Business Horizons, 56(3), $343-350$.

13. Chesbrough, H., 2007. Business model innovation: it's not just about technology anymore. Strategy Leadersh. $35,12-17$. https://doi.org/10.1108/10878570710833714.

14. Chesbrough, H., 2010. Business model innovation: opportunities and barriers. Long Range Plann. 43, 354-363. https://doi.org/10.1016/j.Irp.2009.07.010. 15. Chisholm-Burns, M. A. (2010). A crisis is a really terrible thing to waste. American Journal of Pharmaceutical Education, $74(2), 19$. 
16. Cosh, A., Hughes, A., Bullock, A., \& Milner, I. (2009). SME finance and innovation in the current economic crisis. Centre for Business Research (http://www. cbr. cam. ac. uk/pdf/crcr_econcrisis. pdf).

17. Doshi, H., Kumar, P., Yerramilli, V., 2018. Uncertainty, capital investment, and risk management. Manag. Sci. 64, 5769-5786.

18. De Reuver, M., Bouwman, H., Haaker, T., 2013. Business model roadmapping: a practical approach to come from an existing to a desired business model. Int. J. Innov. Manag. 17, 1340006 https://doi.org/10.1142/S1363919613400069.

19. Eggers, 2020. Masters of disasters? Challenges and opportunities for SMEs in times of crisis. https://doi.org/10.1016/j.jbusres.2020.05.025.

20. Freeman, J., Carroll, G. R., \& Hannan, M. T. (1983). The Liability of Newness: Age Dependence in Organizational Death Rates. American Sociological Review, 48(5), 692-710.

21. Foss, N. J., \& Saebi, T. (2017). Fifteen Years of Research on Business Model Innovation. Journal of Management, 43(1), $200-227$. https://doi.org/10.1177/0149206316675927.

22. GDA (Global Data Analysis), 2020. Coronavirus (COVID-19) Executive Briefing. Global Data.

23. Gherardini, F.; Renzi, C.; Leali, F. A systematic user-centred framework for engineering product design in small- and medium-sized enterprises (SMEs). Int. J. Adv. Manuf. Technol. 2017, 91, 1723-1746.

24. Girotra, K., Netessine, S.:OMforum-business model innovation for sustainability.Manuf. Serv. Oper. Manage. 15(4), 537-544 (2013).

25. Hamel, G., Valikangas, L., 2004. The quest for resilience. Harv. Bus. Rev. 81, 52-63.

26. Hanelt, A., Hildebrandt, B., \& Polier, J. (2015). Uncovering the Role of Is in Business Model Innovation - a Taxonomy-Driven Aproach To Structure the Field. Twenty-Third European Conference on Information Systems (ECIS), (2010), 1-18.

27. Herbane, B., 2010. Small business research: time for a crisis-based view. Int. Small Bus. J. 28, 43-64.

28. Herbane, B. (2013). Exploring crisis management in UK small-and-medium-sized enterprises. Journal of Contingencies and Crisis Management, 21(2), 8295.

29. Hock, M.; Clauss, T.; Schulz, E. The impact of organizational culture on a firm's capability to innovate the business model. R D Manag. 2016, 46, 433-450.

30. Hong, P., Huang, C., \& Li, B. (2012). Crisis management for SMEs: insights from a multiple-case study. International Journal of Business Excellence, 5(5), 535-553.

31. Husin, S.S., Ab Rahman, A.A., Razak, A.A.: A review of business model innovation theories. In: 6th International Seminar on Entrepreneurship and Business (ISEB) (2018).

32. Husin et al., 2021. The Impact of COVID-19: A Need for SMEs to Understand Business Model Innovation. 2, 177-191 https://doi.org/10.1007/978-3-03069221-6_14.

33. Irvine, W., \& Anderson, A. R. (2004). Small tourist firms in rural areas: agility, vulnerability, and survival in the face of crisis. International journal of entrepreneurial behavior \& research.

34. Irvine, W., \& Anderson, A. R. (2006). The impacts of foot and mouth disease on a peripheral tourism area: The role and effect of crisis management. Journal of Travel \& Tourism Marketing, 19(2-3), 47-60.

35. Jonas, A., Mansfeld, Y., Paz, S., \& Potesman, I. (2011). Determinants of Health Risk Perception and How They Shape Tourists' Potential Risk-Taking Behavior: A Case Study of Low-Risk-Taking Tourists. Journal of Travel Research, 50(1), 87-99.

36. Jones, C., Pimdee, P.: Innovative ideas: Thailand 4.0 and the fourth industrial revolution. Asian Int. J. Soc. Sci. 17(1), 32 (2017).

37. Kurschus, R. J., Sarapovas, T., \& Cvilikas, A. (2015). The criteria to identify company's crisis in the SME sector. Engineering Economics, $26(2), 152-158$.

38. Lindgardt, Z., Reeves, M., Stalk, G., \& Deimler, M. S. (2009). Business model innovation. New York: Boston Consulting Group.

39. Lok, Tan Cheng et al., 2021. Crisis Management for Small Business during the COVID-19 Outbreak: Survival, Resilience and Renewal Strategies of Firms in Macau. 2, 1-29.

40. Marolt et al., 2018. SMEs Perspective on Business Model Innovation. P12, 576-591. https://doi.org/10.18690/978-961-286-170-4.40.

41. Mohamad, M.: Cities $4.0+$ Business 4.0 \& Conference \& Exhibition (2018).

42. Mohamad, M. Cities $4.0+$ Business 4.0 \& Conference \& Exhibition (2018).

43. Muñoz, P., Kimmitt, J., Kibler, E., \& Farny, S. (2019). Living on the slopes: entrepreneurial preparedness in a context under continuous threat. Entrepreneurship \& Regional Development, 31(5-6), 413-434.

44. OECD,. Oslo Manuals. Guidelines for Collecting and Interpreting Innovation Data, 3 rd edition, Paris, 2005.

45. Oleskow-szlapka et al., 2017. The level of innovation in SMEs, the determinants of innovation and their contribution to development of value chains. doi: 10.1016/j.promfg.2017.07.367.

46. O'Regan, N.; Ghobadian, A.; Gallear, D. In search of the drivers of high growth in manufacturing SMEs. Technovation 2006, $26,30-41$.

47. Perry, S.C. (2001) 'The relationship between written business plans and the failure of small business in US', Journal of Small Business Management, Vol. 39, No. 3, pp.201-209.

48. Phillipson, J., Bennett, K., Lowe, P., \& Raley, M. (2004). Adaptive responses and asset strategies: the experience of rural micro-firms and Foot and Mouth Disease. Journal of Rural Studies, 20(2), 227-243.

49. Pohle, G., Chapman, M., 2006. IBM's global CEO report 2006: business model innovation matters. Strategy Leadersh. 34, 34-40. https://doi.org/10.1108/10878570610701531. 
50. Rao, H. Raghav et al., 2020. Retweets of officials' alarming vs reassuring messages during the COVID-19 pandemic: Implications for crisis management. $1,1-6$.

51. Ritter, T., Pedersen, C.L., 2020. Analyzing the impact of the coronavirus crisis on business models. Ind. Mark. Manag. 88, $214-224$. https://doi.org/10.1016/j. indmarman.2020.05.014.

52. Ruff, P. \& Aziz, K. (2003). Managing Communications in a Crisis. Hampshire: Gower Publishing Limited.

53. Runyan, R.C. (2006), 'Small business in the face of crisis: identifying barriers to recovery from natural disaster', Journal of Contingencies and Crisis Management, Vol. 14, No. 1, pp.12-26.

54. Saunders, M. N., Gray, D. E., \& Goregaokar, H. (2014). SME innovation and learning: the role of networks and crisis events. European Journal of Training and Development, 38(1-2), 136-149.

55. Sebastian, R.: High Impact real-world digital transformation success stories how companies are reshaping the playing field. In: The Business 4.0, Royale Chulan Kuala Lumpur, Malaysia (2018).

56. Simón-Moya, V., Revuelto-Taboada, L., \& Ribeiro-Soriano, D. (2016). Influence of economic crisis on new SME survival: reality or fiction? Entrepreneurship \& Regional Development, 28(1-2), 157-176.

57. Sorescu et al., 2011. Innovations in Retail Business Models.S15 S3-S16. DOI:10.1016/j.jretai.2011.04.005.

58. Spillan, J.E. and Ziemnowicz, C. (2003) 'Strategic management in small retail businesses', International Small Business Journal, Vol. 21, No. 4, pp.461478.

59. Tannenbaum, C.R., Boyle, R.J., Tandon, V., 2020. Small Businesses and Oil Market Shocked by COVID-19, but Don't Rush Reopening. Advisor Perspectives. https:// www.advisorperspectives.com/commentaries/2020/04/24/small-businesses-and-oil-market-shocked-by-covid-19-but-dont-rush-reopening.

60. Thorgren and Williams, 2020. Staying alive during an unfolding crisis: How SMEs ward off impending disaster. 2, 1-11.

61. Tinku, (2019). Design your business model. P. 109.

62. Williams, T.A., Gruber, D.A., Sutcliffe, K.M., Shepherd, D.A., Zhao, E.Y., 2017. Organizational response to adversity: fusing crisis management and resilience research streams. Acad. Manag. Ann. 11, 733-769.

63. Yin, R.K. (1994). Case Study Research: Design and Methods. Sage, Beverly Hills, CA.

64. Zulkifly, E.: ICO law and legislation: framework and policing. In: Block Chain Solution Asia-Blockchain Revolution the Future of Economy and Humanity, Kuala Lumpur Convention Centre, Malaysia (2018).

\section{Figures}

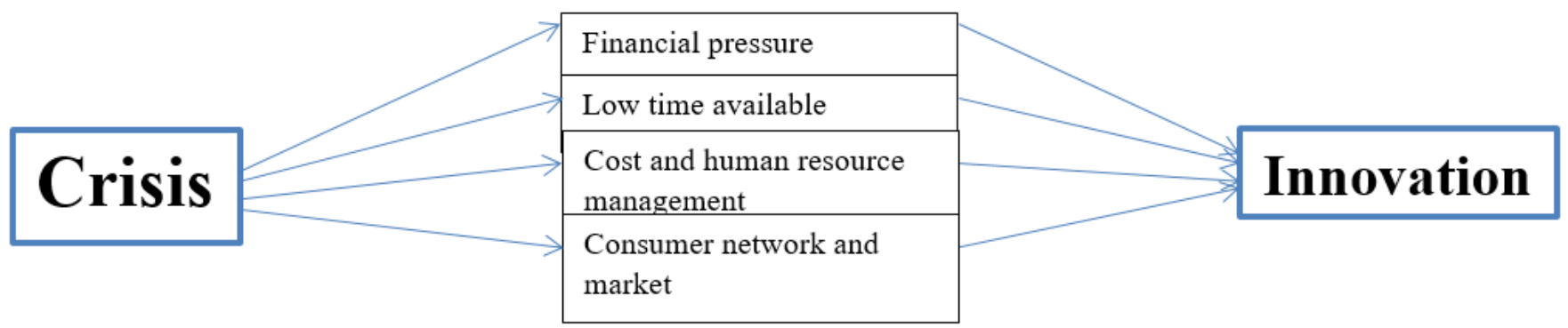

Figure 1

Crisis - Innovation relationship model for small and medium enterprises 